doi: https://doi.org/10.15407/dopovidi2019.02.090

UDC 581.8/631.8

\author{
O.E. Smirnov ${ }^{1}$, L.-A. Karpets ${ }^{1}$, A.V. Zinchenko ${ }^{1}$, \\ M.S. Kovalenko ${ }^{1}$, Ye.O. Konotop ${ }^{1}$, V.V. Schwartau ${ }^{2}$, N.Yu. Taran ${ }^{1}$ \\ ${ }^{1}$ Institute of Biology and Medicine of Taras Shevchenko National University of Kiev \\ ${ }^{2}$ Institute of Plant Physiology and Genetics of the NAS of Ukraine, Kiev \\ E-mail: plantaphys@gmail.com
}

\title{
Aluminum nanoscales as hormetic response effectors in Fagopyrum esculentum seedlings
}

Presented by Corresponding Member of the NAS of Ukraine V.V. Schwartau

Aluminum (Al) nanoscales have been applied in many areas of production industries to produce cosmetic fillers, packaging materials, cutting tools, glass products, metal products, semiconductor materials, plastics, etc. Several studies have demonstrated the contradictory data for positive and negative effects of Al nanoscales on plants. The total length of seedlings grown for 21 days and the relative water content are used to determine the stimulating effects. In addition, the enhancement effect of Al nanoscales on photosynthetic pigments and the total phenolic and anthocyanin contents are determined. The growth stimulation and increase of the content of photosynthetic pigments are observed at the addition of 50 and $250 \mathrm{mg} / \mathrm{L}$ of Al nanoscales. Plant growth stimuli and the fixed beneficial action of Al nanoscales on morphofunctional traits at physiological and biochemical levels are interpreted as the hormesis phenomenon.

Keywords: Al nanoscales, colloidal solution, hormesis, buckwheat seedlings.

Metal- and metal oxide-based nanoscales of titanium dioxide, silver, zinc oxide, cerium dioxide, copper, copper oxide, aluminum, aluminum oxide, nickel, and iron are most commonly used in industries and, therefore, are mostly studied for their influence on different biological objects including plants [1]. Al nanoscales characterized by a high wear-resistance, have good thermal conductivity, resist to strong acids and alkali-containing materials, are easily shaped, and have high strength and stiffness. This makes them a prime material to use in making products that include high-temperature electrical insulators, high-voltage insulators, thermometry sensors, wear pads, ballistic armor, and grinding media [2]. There is no single opinion on the influence of $\mathrm{Al}$ nanoscales on physiological and biochemical processes in plants in the literature available: positive and negative effects are noted. The direct exposure of $\mathrm{Al}$ nanoscales leads to phytotoxic and enhancement alterations in different plants at morphological, cellular, biochemical, and molecular levels [3].

(C) O.E. Smirnov, L.-A. Karpets, A.V. Zinchenko, M.S. Kovalenko, Ye.O. Konotop, V.V. Schwartau, N.Yu. Taran, 2019 
The aim of this study was to investigate the influence of $\mathrm{Al}$ nanoscales colloidal solutions on buckwheat seedlings and to determine their dose-dependent effects on Al-resistant plant species.

Materials and methods. A colloidal solution of Al nanoscales was obtained by the electric-sparkle dispersing of an electric-conductive layer in water [4]. Submicron metal particles in water suspensions were obtained by the method of volumetric electric-spark destruction of metal granules. The pulse power source (thyristor pulse generators with a storage capacitor) was used to initiate the discharge and simultaneous formation of spark channels in contacts between the metal granules dipped into deionized water. The transformation of a liquid to vapor and its condensation with the following crystallization results in the creation of a fraction with size from 10 to $100 \mathrm{~nm}$.

Seeds of common buckwheat (Fagopyrum esculentum Moench. cv. Rubra) were germinated in dark at $25{ }^{\circ} \mathrm{C}$ in Petri dishes with deionized water. After 2 days, seedlings were transferred in pots with sterilized sand and half-diluted Knop solution ( $\mathrm{pH}$ 5.5) in trays. Experiments were conducted under controlled conditions: temperature $-25^{\circ} \mathrm{C}$, photoperiod of $16 \mathrm{~h}$ at a photosynthetic photon flux density of $\approx 200 \mu \mathrm{mol}$ photons $\mathrm{m}^{-2} \cdot \mathrm{s}^{-1}$. For the investigation, 21-day controlled and treated plants were used. The treatment with a colloidal solution of Al nanoscales was performed according to the following scheme: 1 - control, half-diluted Knop medium, 2 - addition of $50 \mathrm{mg} / \mathrm{L} \mathrm{Al}$ nanoscales; 3 - addition of $250 \mathrm{mg} / \mathrm{L} \mathrm{Al}$ nanoscales; 4 - addition of $500 \mathrm{mg} / \mathrm{L}$ Al nanoscales; 5 - addition of $750 \mathrm{mg} / \mathrm{L} \mathrm{Al} \mathrm{nanoscales;} 6$ - addition of $1000 \mathrm{mg} / \mathrm{L}$ $\mathrm{Al}$ nanoscales.

The investigated morphological parameters included the plant total length (TL), fresh biomass (FB), dry biomass (DB), and relative water content of leaves (RWC) [5]. The contents of photosynthetic pigments were determined by measuring the alcohol extract optical density at $662 \mathrm{~nm}$ for chlorophyll $a, 644 \mathrm{~nm}$ for chlorophyll $b$, and $440.5 \mathrm{~nm}$ for carotenoids [6]. FolinCiocalteu reagent was used to determine the total phenolic content [7]. Rutin as the dominant phenolic substance in buckwheat plants was used to standard the curve construction; absorbance was measured at $765 \mathrm{~nm}$ [8]. Total anthocyanin was extracted and estimated by the method of Beggs and Wellmann with some minor modifications [9]. Absorbance was measured at $530 \mathrm{~nm}$. Quantity of anthocyanin was calculated with using cyanidin-3-glucoside coefficients - the major anthocyanin in buckwheat (molar extinction coefficient of $26900 \mathrm{~L} \mathrm{~cm}^{-1} \cdot \mathrm{mol}^{-1}$ and molecular weight of $449.2 \mathrm{~g} \cdot \mathrm{mol}^{-1}$ ). All spectrophotometric assays was measured using a spectrophotometer UV-1800 "Shimadzu" (Japan).

Microsoft Excel 2010 was used for the data statistical analysis. Duncan's multiple range test was used to evaluate the data. The results are expressed as the mean \pm standard deviation, unless noted otherwise. Values of $P \leqslant 0.05$ were considered significant.

Results and discussion. Nowadays, the Buckwheat genus (Fagopyrum Mill.) is one of the most studied Al-resistant crops due to its Al-hyperaccumulating capability [10]. Analysis of the results of morphological traits showed that the total plant length, fresh and dry biomasses per plant were increased in variants with 50 and $250 \mathrm{mg} / \mathrm{L}$ of Al nanoscales. Addition of higher concentrations of nanoparticles $(500,750$, and $1000 \mathrm{mg} / \mathrm{L})$ led to a decrease of the plant growth parameters. Fluctuation of leaf RWC in variants with 50 and $250 \mathrm{mg} / \mathrm{L}$ of $\mathrm{Al}$ nanoscales was not detected. Level of RWC in leaves in variants with 500, 750, and $1000 \mathrm{mg} / \mathrm{L}$ of Al nanoscales showed a significant increase of the water deficit (Table). 


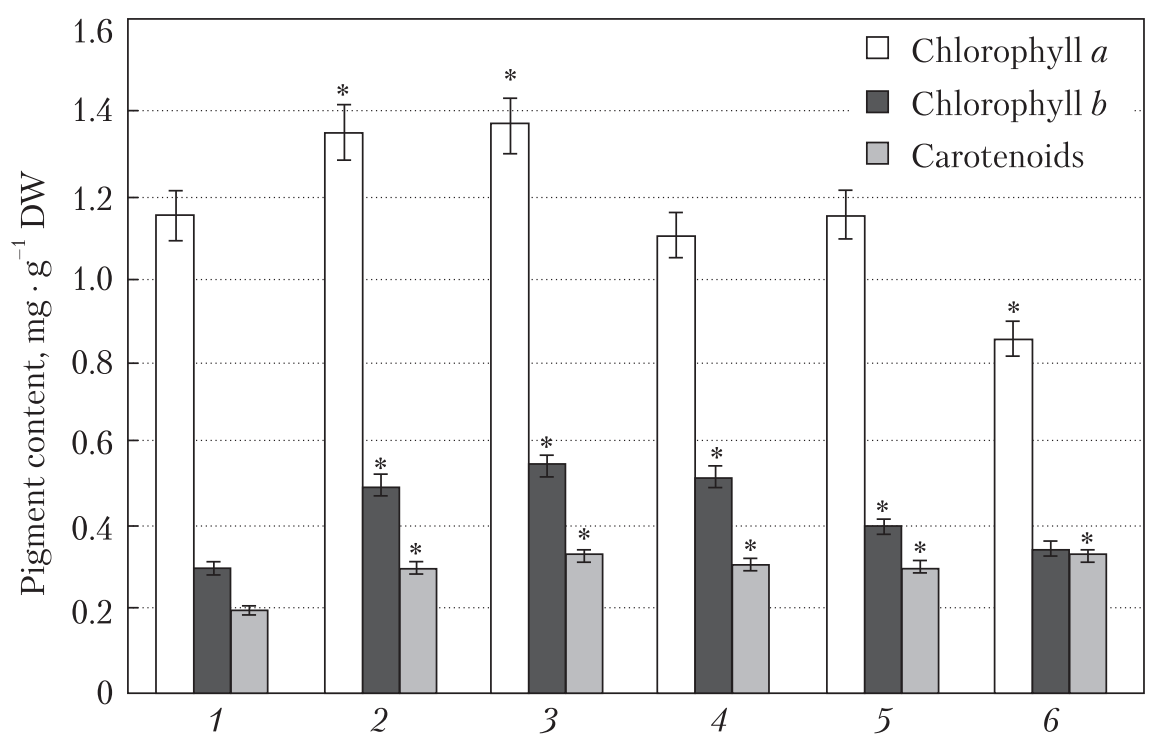

Fig. 1. Photosynthetic pigments content in buckwheat leaves under the treatment with colloidal solutions of Al nanoscales: 1 - control, half-diluted Knop medium, 2 - $50 \mathrm{mg} / \mathrm{L} \mathrm{Al}$ nanoscales; 3 - $250 \mathrm{mg} / \mathrm{L}$ Al nanoscales; $4-500 \mathrm{mg} / \mathrm{L} \mathrm{Al}$ nanoscales; $5-750 \mathrm{mg} / \mathrm{L} \mathrm{Al}$ nanoscales; $6-1000 \mathrm{mg} / \mathrm{L} \mathrm{Al}$ nanoscales; * - difference significant at $P \leqslant 0.05(M \pm S D ; n=10)$

Morphological traits of buckwheat seedlings under the treatment with colloidal solutions of Al nanoscales

\begin{tabular}{|c|c|c|c|c|}
\hline $\begin{array}{c}\text { Variant of } \\
\text { treatment }\end{array}$ & Plant length, cm & $\begin{array}{c}\text { Fresh biomass, } \\
\text { mg per plant }\end{array}$ & $\begin{array}{c}\text { Dry biomass, } \\
\text { mg per plant }\end{array}$ & $\begin{array}{c}\text { Leaf relative } \\
\text { water content, \% }\end{array}$ \\
\hline 1 & $23.05 \pm 0.31$ & $197.43 \pm 3.7$ & $20.35 \pm 0.78$ & 87.7 \\
2 & $24.78 \pm 0.44^{*}$ & $209.27 \pm 3.1^{*}$ & $21.07 \pm 0.65^{*}$ & 86.9 \\
3 & $24.67 \pm 0.37^{*}$ & $211.58 \pm 4.5^{*}$ & $21.82 \pm 0.67^{*}$ & 88.7 \\
4 & $22.21 \pm 0.23^{*}$ & $188.73 \pm 4.3^{*}$ & $19.57 \pm 0.74^{*}$ & 70.6 \\
5 & $20.35 \pm 0.48^{*}$ & $156.05 \pm 5.0^{*}$ & $14.72 \pm 0.56^{*}$ & 66.7 \\
6 & $18.93 \pm 0.36^{*}$ & $153.91 \pm 4.2^{*}$ & $14.39 \pm 0.81^{*}$ & 54.3 \\
\hline
\end{tabular}

* Difference significant at $P \leqslant 0.05(M \pm S D ; n=20)$.

The whole plant growth fluctuation under nanoscales treatments is the most evident trait of the plant functional status and becomes a useful bioassay due to its normativity, simplicity, nondestructivity, and sensitivity [11]. In turn, RWC is probably the most appropriate trait of the plant water balance in terms of the physiological consequence of a plant water deficit, since water accounts for $80-90 \%$ of the fresh weight of most herbaceous plant structures. Analysis of morphometric results considered that the addition of Al nanoscales in concentrations of 500, 750, and $1000 \mathrm{mg} / \mathrm{L}$ was perceived as a stress condition accompanied by the growth inhibition and water balance disruption. Low concentrations of $\mathrm{Al}$ nanoscales (50 and $250 \mathrm{mg} / \mathrm{L}$ ) led to the fresh and dry biomass accumulation and did not cause changes in the water status of treated plants. 


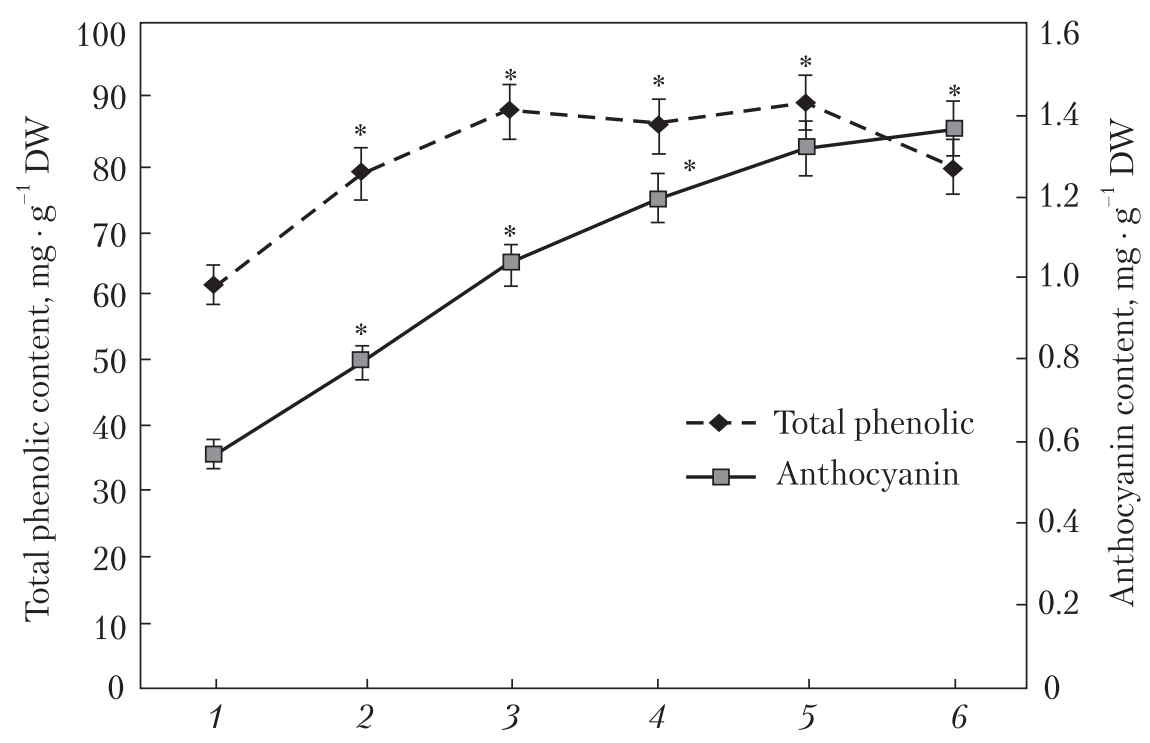

Fig. 2. Total phenolic and anthocyanin content in buckwheat leaves under the treatment with colloidals solution of Al nanoscales: 1 - control, half-diluted Knop medium; $2-50 \mathrm{mg} / \mathrm{L} \mathrm{Al}$ nanoscales; $3-250 \mathrm{mg} / \mathrm{L}$ Al nanoscales; 4 - $500 \mathrm{mg} / \mathrm{L}$ Al nanoscales; $5-750 \mathrm{mg} / \mathrm{L}$ Al nanoscales; 6 - $1000 \mathrm{mg} / \mathrm{L}$ Al nanoscales; * - difference significant at $P \leqslant 0.05(M \pm S D ; n=10)$

Our study showed a significant fluctuation of the photosynthetic pigment content under the $\mathrm{Al}$ nanoscales treatment (Fig. 1).

Enhancement effects of $\mathrm{Al}$ nanoscales on all pigments classes were noted in variants with 50 and $250 \mathrm{mg} / \mathrm{L}$. The increases of chlorophyll $b$ and carotenoids were observed in variants with 500 and $750 \mathrm{mg} / \mathrm{L}$ of $\mathrm{Al}$ nanoscales. Our results of the study of the influence of $\mathrm{Al}$ nanoscales on the photosynthetic pigments content showed significant increases of chlorophylls and carotenoids in variants with treatment by 50 and $250 \mathrm{mg} / \mathrm{L}$ of Al nanoscales. Ascending the nanoscales concentration to $1000 \mathrm{mg} / \mathrm{L}$ led to decreasing the chlorophyll $a$ content, while the contents of chlorophyll $b$ and carotenoids remained above the control level. These pigments are considered adaptogens due to adaptive capabilities of molecules, which consist in quenching an excited state of chlorophyll and preventing the formation of singlet oxygen and other reactive oxygen species [12].

The results of the study of the effects of $\mathrm{Al}$ nanoscales on the phenolic and anthocyanin contents showed that the addition of nanoscales induced the anthocyanins accumulation with a dosedependent relation (Fig. 2).

Total phenolic compounds and anthocyanins are also able to function as potential antioxidants and are involved in the adaptive response under stressors influence [13]. The most significant increasing of anthocyanins was fixed in the variant with the maximal $1000 \mathrm{mg} / \mathrm{L}$ concentration of $\mathrm{Al}$ nanoscales - addition of $1000 \mathrm{mg} / \mathrm{L}$ of $\mathrm{Al}$ nanoscales led to the maximum stimulatory response $-241 \%$ of the control level. The sharp increase of the total phenolic content fixed in all variants of $\mathrm{Al}$ nanoscales treatments. The total phenolic content showed no significant difference between variants with 250, 500, 750, and $1000 \mathrm{mg} / \mathrm{L}$. After a sharp increase in the variant with $250 \mathrm{mg} / \mathrm{L}$ of Al nanoscales, the total phenolic content remained at $130-145 \%$ of the control level. 
While some results have been concerned with the toxicity of $\mathrm{Al}$ nanoscales to plants, others have focused on the possibility of using $\mathrm{Al}$ nanoscales as a fertilizer seeing enhancement effects. It was showed that, at the addition of certain concentrations of Al nanoscales, the plant growth, photosynthetic pigments, total phenolic and anthocyanin contents increase. Our experiments have provided evidence to characterize the morphofunctional responses of buckwheat plants as the hormesis - a dose-response phenomenon with the low-dose stimulation and high-dose inhibition [14].

Conclusions. Thus, the presence of aluminum nanoscales in low concentrations (50 and $250 \mathrm{mg} / \mathrm{L}$ ) induced the plant growth, phenolic compounds, anthocyanin accumulation, and led to increasing the chlorophylls and carotenoids content. Shoot and root growth stimuli and fixed beneficial action of $\mathrm{Al}$ nanoscales on morphofunctional traits at physiological and biochemical levels were interpreted as the hormesis phenomenon.

The publication contains the results of studies supported by President's of Ukraine grant № F75/170-2018 for competitive projects of the State Fund for Fundamental Research.

\section{REFERENCES}

1. Rastogi, A., Zivcak, M., Sytar, O., Kalaji, K. M., He, X., Mbarki, S. \& Brestic, M. (2017). Impact of metal and metal oxide nanoparticles on plant: a critical review. Front. Chem., 5, 78. doi: https://doi.org/10.3389/ fchem.2017.00078

2. Burklew, C. E., Ashlock, J., Winfrey, W. B. \& Zhang, B. (2012). Effects of aluminum oxide nanoparticles on the growth, development, and microRNA expression of tobacco (Nicotiana tabacum). PLoS One, 7, No. 5, e34783. doi: https://doi.org/10.1371/journal.pone.0034783

3. Jampílek, J. \& Králová, K. (2017). Nanomaterials for delivery of nutrients and growth promoting compounds to plants. In Prasad, R., Kumar, M., Kumar, V. (Eds). Nanotechnology. An Agricultural Paradigm (pp. 117-227). Springer Nature Singapore Pte Ltd.

4. Pat. 38459 UA, IPC B01J 13/00, Mother colloidal solution of metals, Lopatko, K.G., Aftandilyants, E.H., Kalenska, S.M. \& Tonkha, O.L., Publ. 12.01.2009 (in Ukrainian).

5. Munzuroglu, O. \& Geckil, H. (2002). Effects of metals on seed germination, root elongation, and coleoptile and hypocotyl growth in Triticum aestivum and Cucumis sativus. Arch. Environ. Contam. Toxicol., 43, pp. 203-213. doi: https://doi.org/10.1007/s00244-002-1116-4

6. Lichtethaler, H. K. (1987). Chlorophylls and pigments of photosynthetic biomembranes. Methods Enzymol., 148, pp. 350-82. doi: https://doi.org/10.1016/0076-6879(87)48036-1

7. Bobo, G., Davidov-Pardo, G., Arroqui, C., Vírseda, P., Marín-Arroyo, M. R. \& Navarro, M. (2015). Intralaboratory validation of microplate methods for total phenolic content and antioxidant activity on polyphenolic extracts, and comparison with conventional spectrophotometric method. J. Sci. Food Agric., 95, No. 1, pp. 204-209. doi: https://doi.org/10.1002/jsfa.6706

8. Li, X., Kim, J. K., Park, S. Y., Zhao, S., Kim, Y. B., Lee, S. \& Park, S. U. (2014). Comparative analysis of flavonoids and polar metabolite profiling of Tanno-original and Tanno-high rutin buckwheat. J. Agric. Food Chem., 62, No. 12, pp. 2701-2708. doi: https://doi.org/10.1021/jf4049534

9. Smirnov, O. E., Kosyan, A. M., Kosyk, O. I. \& Taran, N. Y. (2015). Response of phenolic metabolism induced by aluminium toxicity in Fagopyrum esculentum Moench. Plants. Ukr. Biochem. J., 87, pp. 129-135. doi: https://doi.org/10.15407/ubj87.06.129

10. Shen, R. \& Ma, J. F. (2001). Distribution and mobility of aluminium in an Al-accumulating plant Fagopyrum esculentum Moench. J. Exp. Bot., 52, No. 361, pp. 1683-1687.

11. Srinivasa Rao, N. K., Shivashankara, K. S. \& Laxman, R. H. (2016). Abiotic stress physiology of horticultural crops. New Delhi: Springer. doi: https://doi.org/10.1007/978-81-322-2725-0

12. Sun, Y. P., Li, X. Q., Cao, J., Zhang, W. X. \& Wang, H. P. (2006). Characterization of zero-valent iron nanoparticles. Adv. Colloid Interface Sci., 120, pp. 47-56. https://doi.org/10.1016/j.cis.2006.03.001 
13. Michalak, A. (2006). Phenolic compounds and their antioxidant activity in plants growing under heavy metal stress. Polish J. Environ. Stud., 15, No. 4, pp. 523-530.

14. Calabrese, E. J. \& Blain, R. B. (2009). Hormesis and plant biology. Environ. Pollut., 157, pp. 42-48. doi: https://doi.org/10.1016/j.envpol.2008.07.028

Received 03.12.2018

О.С. Смірнов ${ }^{1}$, Л.-А. Карпець ${ }^{1}$, А.В. Зінченко ${ }^{1}$, М.С. Коваленко ${ }^{1}$,

C.О. Конотоп ${ }^{1}$, В.В. Швартау ${ }^{2}$, Н.Ю. Таран ${ }^{1}$

${ }^{1}$ ННЦ “Інститут біології та медицини”

Київського національного університету ім. Тараса Шевченка

2 Інститут фізіології рослин і генетики НАН України

E-mail: plantaphys@gmail.com

\section{НАНОЧАСТИНКИ АЛЮМІНІЮ ЯК ГОРМЕТИЧНІ ЕФЕКТОРИ В ПРОРОСТКАХ FAGOPYRUM ESCULENTUM}

Наночастинки алюмінію (Al) використовуються у багатьох сферах промислового виробництва для отримання косметичних наповнювачів, пакувальних матеріалів, різальних матеріалів, виробів зі скла, металевих виробів, матеріалів з напівпровідниковими властивостями, пластмас тощо. Існують суперечливі дані про позитивні та негативні ефекти наночастинок $\mathrm{Al}$ на рослини. Запропоновано для визначення стимулюючих ефектів наночастинок Al використовувати загальну довжину 21-добових проростків та відносну тургесцентність. Крім того, визначено позитивний вплив наночастинок $\mathrm{Al}$ на вміст фотосинтетичних пігментів, загальний вміст фенольних сполук та антоціанів. Додавання наночастинок $\mathrm{Al}$ у концентрації 50 та 250 мг/л спричиняє стимуляцію росту та збільшення вмісту фотосинтетичних пігментів. Стимуляція росту рослин і позитивний вплив наночастинок $\mathrm{Al}$ на морфофункціональні характеристики на фізіологічному та біохімічному рівнях інтерпретовані як феномен гормезису.

Ключові слова: наночастинки алюмінію, колоїд, гормезис, проростки гречки.

А.Е. Смирнов ${ }^{1}$, Л.-А. Карпеи ${ }^{1}$, А.В. Зинченко ${ }^{1}$, М.С. Коваленко ${ }^{1}$, Е.А. Конотоп ${ }^{1}$, В.В. Швартау ${ }^{2}$, Н.Ю. Таран ${ }^{1}$

${ }^{1}$ унц “Институт биологии и медицины”

Киевского национального университета им. Тараса Шевченко

${ }^{2}$ Институт физиологии растений и генетики НАН Украины, Киев

E-mail: plantaphys@gmail.com

\section{НАНОЧАСТИЦЫ АЛЮМИНИЯ КАК ГОРМЕТИЧЕСКИЕ ЭФФЕКТОРЫ В ПРОРОСТКАХ FAGOPYRUM ESCULENTUM}

Наночастицы алюминия (Al) используются во многих сферах промышленного производства для получения косметических наполнителей, упаковочных материалов, режущих материалов, изделий из стекла, металлических изделий, материалов с полупроводниковыми свойствами, пластмасс и т. п. Существуют противоречивые данные о положительных и отрицательных эффектах наночастиц $\mathrm{Al}$ на растения. Предложено для определения стимулирующих эффектов наночастиц $\mathrm{Al}$ использовать общую длину 21-суточных проростков и относительную тургесцентность. Кроме того, определено положительное влияние наночастиц $\mathrm{Al}$ на содержание фотосинтетических пигментов, общее содержание фенольных соединений и антоцианов. Добавление наночастиц $\mathrm{Al}$ в концентрации 50 и 250 мг/л приводит к стимуляции роста и увеличению содержания фотосинтетических пигментов. Стимуляция роста растений и положительное влияние наночастиц $\mathrm{Al}$ на морфофункциональные характеристики на физиологическом и биохимическом уровнях интерпретированы как феномен гормезиса.

Ключевые слова: наночастищы алюминия, коллочд, гормезис, проростки гречихи. 